\title{
Spatio-temporal variability in debris-flow activity: a tree-ring study at Geisstriftbach (Swiss Alps) extending back to AD 1736
}

\author{
Markus Stoffel • Michelle Bollschweiler • \\ Susanne Widmer • Annina Sorg
}

Received: 22 September 2009/ Accepted: 2 May 2010/Published online: 10 August 2010

(C) Swiss Geological Society 2010

\begin{abstract}
Past debris-flow activity on the forested cone of the Geisstriftbach torrent (St. Niklaus, Valais, Swiss Alps) was assessed from growth disturbances in old conifer trees, providing a much improved record of past events. The study of 633 tree-ring sequences sampled from 252 European larch (Larix decidua Mill.), Norway spruce (Picea abies (L.) Karst.) and Silver birch (Betula pendula Roth.) trees allowed reconstruction of 53 debris-flow events since AD 1736. The spatial analysis of trees affected during particular events on the geomorphic map allowed for a spatial representation of individual events and a reconstruction of four flow patterns. Based on our results and Siegfried maps, we believe that before the formation of a dogleg near the cone apex in the late 1890s, debris flows preferentially used the channels located in the west-
\end{abstract}

Editorial handling: D. Ariztegui \& S. Bucher.

M. Stoffel $(\bowtie) \cdot$ M. Bollschweiler

Laboratory of Dendrogeomorphology (dendrolab.ch), Institute of Geological Sciences, University of Bern,

Baltzerstrasse 1+3, 3012 Bern, Switzerland

e-mail: markus.stoffel@dendrolab.ch

M. Stoffel · M. Bollschweiler

Climatic Change and Climate Impacts Group (C3i),

Institute for Environmental Sciences, University of Geneva,

7, route de Drize, Carouge, 1227 Geneva, Switzerland

S. Widmer

Katastrophenvorsorge, Amt für Militär und Bevölkerungsschutz,

Kanton Solothurn, Baselstrasse 40, 4500 Solothurn, Switzerland

A. Sorg

Department of Environmental Sciences, Forest Ecology, Institute of Terrestrial Ecosystems, Swiss Federal Institute of Technology of Zurich (ETHZ), 8092 Zurich, Switzerland southwestern part of the Geisstriftbach cone. This study contributes to our understanding of debris-flow processes on cones and provides an example of how dendrogeomorphic techniques may help in the reconstruction and understanding of debris flows in Alpine areas.

Keywords Debris flow · Tree ring .

Dendrogeomorphology · Larix decidua Mill. .

Picea abies (L.) Karst

\section{Introduction}

Debris flows represent one of the most common and widespread of all natural hazards in mountain regions, where they endanger the security of humans and also damage their assets. Through their high flow velocity and poor temporal predictability, debris flows are commonly considered one of the most dangerous landslide types (Jakob and Hungr 2005). In Switzerland, federal regulations require cantonal authorities to compile hazard maps, which are needed for land-use planning and in the design of protection measures (Raetzo et al. 2002). From this perspective, a spatio-temporal reconstruction of past debrisflow activity is essential to appraise the process and to overcome the considerable lack of archival records.

On forested cones, debris flows can destroy or damage trees in or adjacent to their flow paths. Woody vegetation physically damaged by debris flows or growing on their deposits provides a means for dating and interpreting past events. Alestalo (1971) has coined the term "dendrogeomorphology", a method that aims at inferring the history of geomorphic process activity from information preserved in tree rings. Past dendrogeomorphic work on debris flows primarily used tree-ring records of conifer trees and 
focused on the reconstruction of event frequencies (Strunk 1997; Bollschweiler and Stoffel 2010) or magnitudes (Stoffel 2010), the extent of previous activity on cones and in channels (Bollschweiler et al. 2007; Stoffel et al. 2008b; Mayer et al. 2010), germination dates of successor trees growing in abandoned flow paths (Bollschweiler et al. 2008a), the synchronicity of debris-flow activity in neighboring watersheds with different lithologies (Bollschweiler and Stoffel 2007), the comparison of reconstructed debrisflow data with archival records on flooding (Stoffel et al. 2005a) or on changes in the seasonality of debris-flow activity with time (Stoffel et al.2008a, in review). More recently, studies have included broad-leaved trees growing inside or next to debris-flow channels so as to take account of more recent as well as of smaller in-channel events (e.g., Arbellay et al. 2010; Szymczak et al. 2010).

It is the purpose of this paper to reconstruct spatial patterns of as well as temporal changes in debris-flow activity on the cone of the Geisstriftbach torrent (Mattertal, Valais, Swiss Alps) based on conifer trees. Through the identification of surface deposits of debris flows and the analysis of 633 tree-ring series obtained from 252 trees disturbed by past incidences, we (1) investigate the frequency of debris-flow events, (2) analyze activity in abandoned channels, and (3) discuss possible effects of changes in climatic conditions upon debris-flow activity of this torrent originating from periglacial environments.

\section{Study site}

The study was conducted along the debris-flow channel of the Geisstriftbach torrent, located on the west-facing slope of the Mattertal Valley (Valais, Switzerland, $46^{\circ} 07^{\prime} \mathrm{N}$, $7^{\circ} 47^{\prime} \mathrm{E}$; Fig. 1). The catchment area of the Geisstriftbach totals $5 \mathrm{~km}^{2}$ and extends from the Gugla (3,377 m a.s.l.) and Dirrehorn summits $(4,035 \mathrm{~m}$ a.s.1.) to the torrent's confluence with the Mattervispa river at $1,260 \mathrm{~m}$ a.s.l. In the source area of the Geisstriftbach torrent, a surging rockglacier body yields considerable amounts of sediment into the debris-flow system.

The gradient between the source area and the cone is high and results in steep torrent topography. Geology consists of gneissic lithologies belonging to the crystalline Mischabel unit (Labhart 2004), while in the lower part, debris originating from various gravitational processes (i.e., rockslides, rockfall) covers bedrock. A majority of the upper catchment is well above tree line and characterized by steep slopes with scarce vegetation.

The debris-flow cone extends from 1,270 to $1,350 \mathrm{~m}$ a.s.l. and is covered with a forest composed primarily of conifer trees (Fig. 2). In the uppermost part of the debrisflow cone, Silver birch (Betula pendula Roth.) and European rowan (Sorbus aucuparia L.) determine the aspect, whereas in the lower part, European larch (Larix decidua Mill.) and Norway spruce (Picea abies (L.)
Fig. 1 The Geisstriftbach study site is located in the Mattertal valley (Valais, Switzerland) between the villages of Herbriggen and Randa. The catchment of the Geisstriftbach torrent (area: $5 \mathrm{~km}^{2}$ ) extends from the cone apex at $1,350 \mathrm{~m}$ a.s.l. to $4,035 \mathrm{~m}$ a.s.l. (Dirrehorn summit) and contains a large rock-glacier in the source area of the torrent

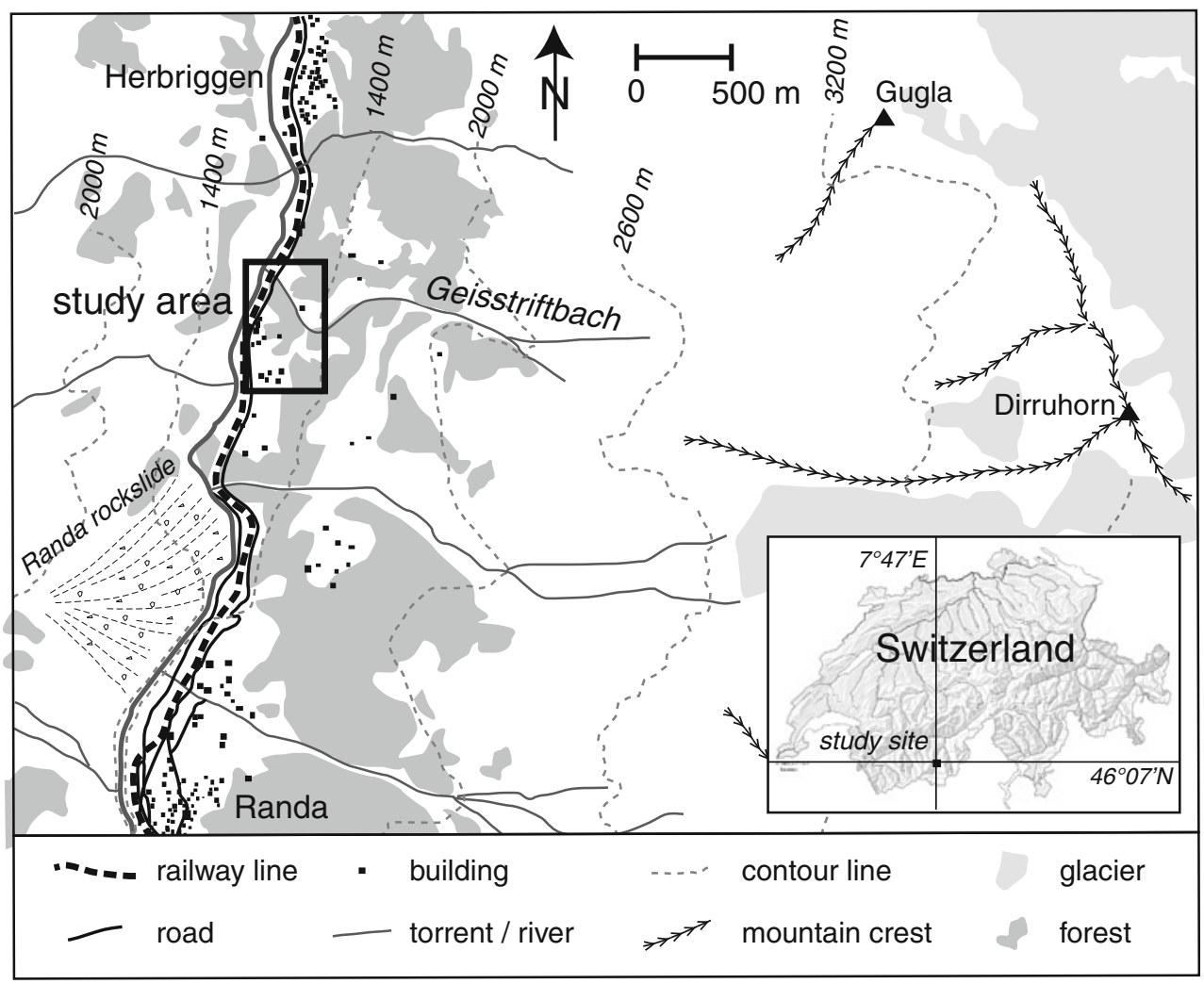


Fig. 2 Impressions of debrisflow deposits on the Geisstriftbach cone with the current channel (left) and a large lobate deposit (right). Note that the trees illustrated have been affected by past debris-flow activity
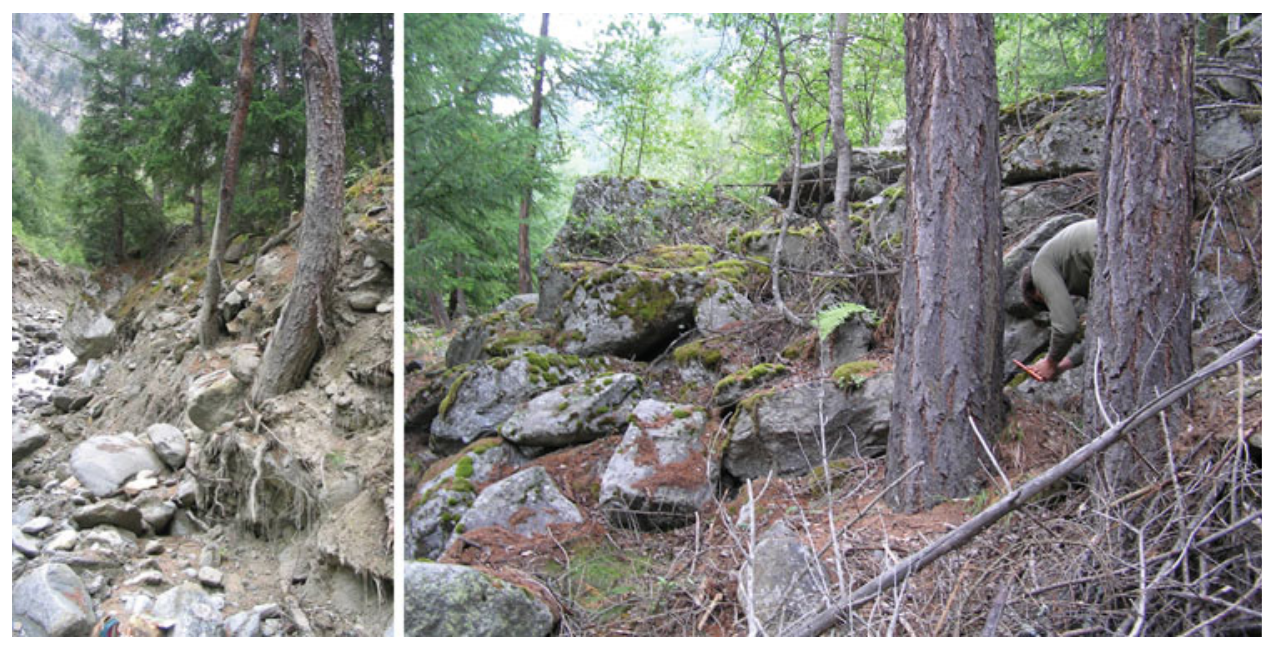

Karst.) are dominant (Sorg et al. 2010). Most trees on the cone show morphological evidence of past process activity. While growth anomalies in the uppermost segment of the cone may stem either from debris-flow or infrequent snow avalanche activity, signs of snow avalanches are completely absent in the lower and lateral parts of the cone.

Anthropogenic influence on the cone is most pronounced in its northern part today, where the land is used as pasture, but it can be assumed that pasture activity was much more intense and widespread in the last centuries than today. The main road and railway line connecting Visp to Zermatt are located in the lowermost part of the debris-flow cone, where the Geisstriftbach merges into the Mattervispa.

Data on past debris-flow events in the Geisstriftbach is scarce and only covers the last three decades (1978, 1993 and 1997; SRCE 2007). During the event in 1997, several $10,000 \mathrm{~m}^{3}$ of debris were mobilized from the periglacial departure zone.

\section{Materials and methods}

\section{Geomorphic mapping}

Fieldwork started with the mapping of all features associated with previous debris-flow activity such as levees, lobes or abandoned channels in a scale of 1:1,000. At the same time, we identified areas affected by debris flows and snow avalanches and excluded them for further analysis and in order to avoid misinterpretation of tree reactions. As a result of the dense forest cover and the shielding effect of the steep valley walls, GPS devices could not be used at Geisstriftbach and therefore geomorphic mapping utilized a tape, inclinometer and compass.
Trees, tree rings and debris flows: field approach

The basic principles of tree-ring dating have been outlined extensively by Alestalo (1971), Shroder (1980) or Stoffel et al. (2010). Dendrogeomorphology is based on the fact that (1) trees form one increment ring per year in temperate climates and that (2) trees affected by geomorphic processes will record the event in the form of characteristic growth disturbances (GD) in their tree-ring series. Through the determination of the position of the GD within a tree ring, it is not only possible to date a geomorphic process to the year, but sometimes even to the season (i.e., monthly resolution; Stoffel et al. 2006; Stoffel and Beniston 2006).

On the debris-flow cone of the Geisstriftbach, a majority of the L. decidua and $P$. abies trees show visible GD relating to past debris-flow activity in the form of tilted stems, partial burial of the trunk, destruction of the root mass or corrasion scars An overview of the different anomalies of tree growth and related GD in the tree-ring series is given in Fig. 3.

At least two cores were extracted per tree using increment borers, one in the flow direction of past debris flows and the other on the opposite side of the trunk (maximum length of cores: $40 \mathrm{~cm}$ by $6 \mathrm{~mm}$ ). In order to gather the greatest amount of information on GD caused by past events, increment cores were preferably sampled at the height of the visible damage or within the segment of the stem tilted during past events. In the case of visible scars, further increment cores were extracted from the wound and the overgrowing callus (Schneuwly et al. 2009a, b). In total, 252 trees were sampled (614 increment cores, 18 cross sections, and one stem wedge). We primarily sampled L. decidua (237 trees) and complemented the dataset with eleven $P$. abies and four $B$. pendula.

In addition to the disturbed trees sampled on the cone, we used data from undisturbed reference trees from a 
Fig. 3 Dendrogeomorphic evidence used to infer debrisflow events (modified after Stoffel et al. 2005b and Bollschweiler and Stoffel 2007)

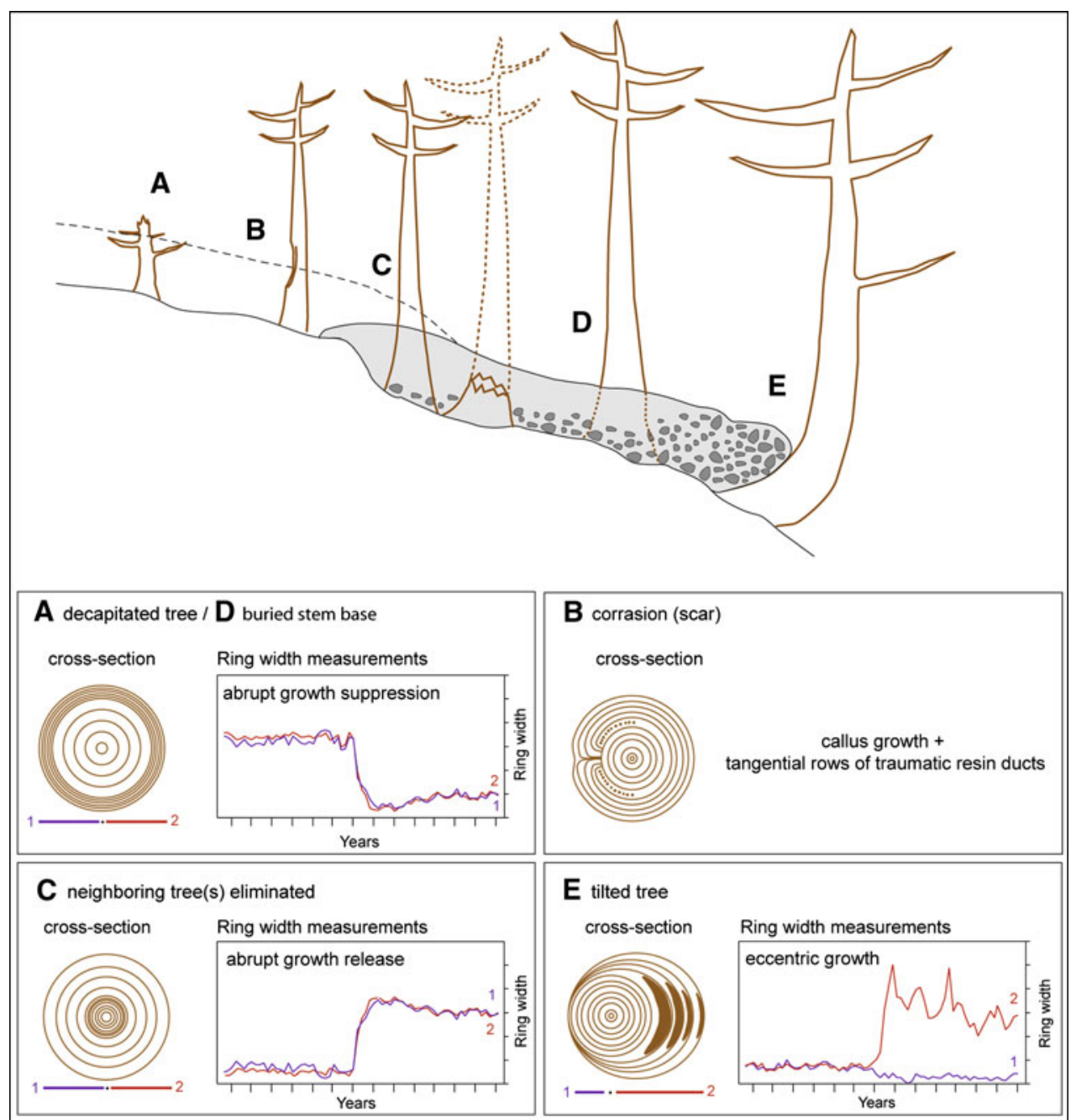

nearby forest stand (Bollschweiler et al. 2008a). For each reference tree, two cores were extracted parallel to the slope direction. In contrast to the disturbed trees, increment cores of the reference trees were extracted at breast height $(\approx 130 \mathrm{~cm})$.

\section{Tree-ring analysis}

In the laboratory, tree samples were analyzed and data processed following the standard procedures described in Stoffel and Bollschweiler (2008, 2009). Single steps of sample analysis included surface preparation and ringwidth measurements using digital LINTAB positioning tables connected to a Leica stereomicroscope and TSAP 6.43 (Time Series Analysis and Presentation) software (Rinntech 2009). Growth curves of the disturbed samples were then cross-dated with the corresponding reference chronology constructed from undisturbed trees to separate insect attacks or climatically driven fluctuations in tree growth from GD caused by debris flows (Cook and Kairiukstis 1990).
As illustrated in Fig. 3, growth curves were then used to determine the initiation of abrupt growth reduction or recovery (McAuliffe et al. 2006). In the case of tilted stems, both the appearance of the cells (i.e., geometry of the reaction wood cells) and the growth curve data were analyzed (e.g., Braam et al. 1987; Fantucci and SorrisoValvo 1999).

Finally, cores were visually inspected so as to identify further signs of past debris-flow activity. The corrasion of tree stems causes cambium damage (cambium $=$ woodproducing tissue) and results in the formation of callus tissue overgrowing these scars (Hupp 1984). Another typical feature in L. decidua and $P$. abies trees are tangential rows of traumatic resin ducts (TRD; Stoffel 2008), which are formed as a means of protection against insect attacks and pathogens following cambium damage (Bollschweiler et al. 2008b; Stoffel and Hitz 2008). As a rule, the first two decades of juvenile growth have not been included in the analysis, as tree rings in seedlings tend to be more susceptible to snow pressure and produce more resin ducts per unit area in general. 
Reconstructing frequency and assessing spatial patterns of past events

After the dating of GD on the samples, the identification of events was based (1) on the number of samples simultaneously showing a growth disturbance as well as (2) on the distribution of affected trees on the cone. GD occurring simultaneously in different trees were grouped and criteria defined for the determination of events. In this study, we distinguish between well replicated events and events which are only present in a limited number of tree-ring series. In addition, we positioned all trees with GD resulting from the same event on the geomorphic map so as to reconstruct the minimum spatial extent of events on the cone and to assess activity in currently abandoned channels.

\section{Results}

Geomorphic map

Geomorphic mapping permitted identification of 62 features relating to past debris-flow activity on the cone of the Geisstriftbach torrent. The features and deposits inventoried in the study area covering 5 ha are illustrated in Fig. 4 and included 15 lobes, 43 levees and four well-developed debris-flow channels. The length of lateral levees varies from a few to several dozens of meters. While some of these lateral levees appear quite isolated on the actual surface of the cone others can easily be attributed to channels that were in use sometimes in the past. The tracks of these paleochannels are still clearly visible in the western and west-southwestern parts of the cone, although their banks have collapsed partially and their beds are now filled with fallen debris and vegetation.

Tree age and growth disturbances

The average age of the 252 trees selected at Geisstriftbach was 91 year ( $\sigma=46$ year) at sampling height. Counted tree rings ranged from 27 (AD 1979) to 304 (AD 1702). We observe a concentration of older trees along the abandoned channel in the southeastern segments of the cone. The youngest trees, in contrast, are most commonly found next to the channel and near the forest fringe, where anthropogenic intervention has affected tree age and germination rates (i.e., farming activities, extraction of fireand construction-wood).

Dendrogeomorphic analyses of the 614 increment cores and 19 cross-sections or wedges permitted the detection of 1,344 growth disturbances (GD) relating to past debris flows. Signatures of past events are mainly preserved on the increment cores via tangential rows of traumatic resin

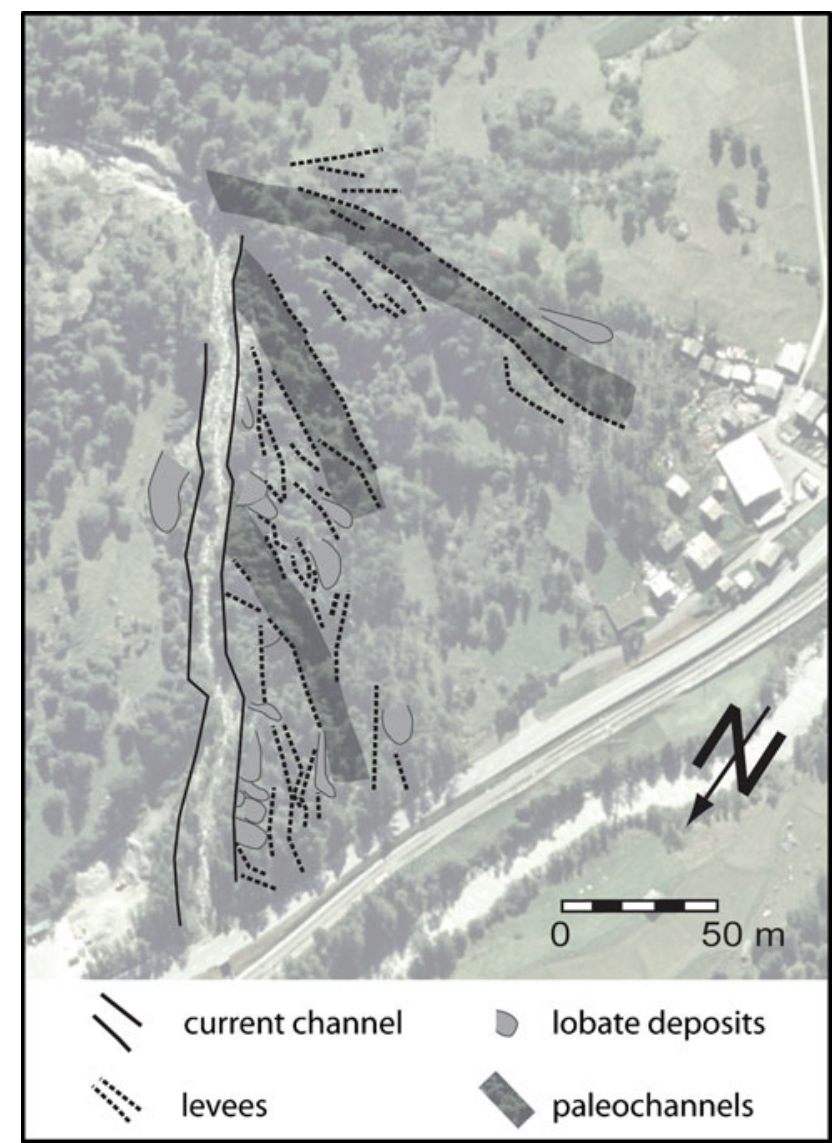

Fig. 4 Geomorphic map of the debris-flow cone with lobes (black surfaces), levees (dashed lines) and channels (orthophoto: (C) swisstopo 2010 , used with permission)

ducts $(71.3 \%)$ resulting from cambium damage or via compression wood $(15.8 \%)$ produced after stem tilting. Growth recovery following an elimination of neighboring trees was found in $1.7 \%$ of the samples and a sudden growth suppression following tree topping, root exposure or stem burial was present in $8.6 \%$. As L. decidua and $P$. abies trees are quickly healing wounds and masking their scars, injuries or the adjacent callus tissues were only rarely present in the cores (1.6 and $1.0 \%$, respectively). Figure 5 illustrates characteristic examples of GD observed in the tree-ring series sampled at Geisstriftbach. Figure 5a shows the increment curves of a $P$. abies tree tilted by debris-flow material in AD 1918. As a result, the tree initiated the formation of compression wood cells on the tilted side of its trunk (i.e. core d) so as to stabilize itself and to regain a vertical position. The tree is investing most of its energy into the formation of compression wood, this is why tree rings start to become smaller on the upslope side of the stem (core c) following the debris-flow event of 1918. Figure $5 \mathrm{~b}$ illustrates the tree-ring series of a $L$. decidua tree showing a buried stem basis. Based on the dendrogeomorphic record, we can date this stem burial to AD 1798 . 

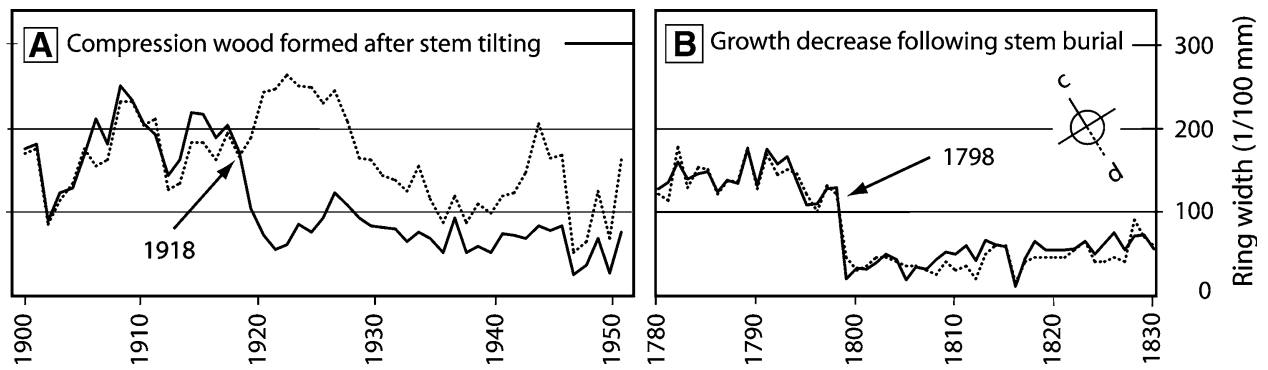

Fig. 5 Examples of growth disturbances inferred by debris-flow activity: a after tilting in $\mathrm{AD} 1918$, this $P$. abies tree initiated the formation of compression wood cells on the tilted side of its trunk (i.e. core d) so as to regain a vertical position. Most of the tree's energy is

Debris-flow frequency and spatial patterns of past events

The analysis of GD occurring simultaneously in different trees allowed for a reconstruction of 53 debris-flow events since AD 1736. Figure 6 illustrates the reconstructed frequency series, indicating that the dating of 31 events was based on a very large number of GD (represented with bold lines). In contrast, for the 22 events represented with dashed lines, there is good evidence for the existence of events in these years as well, but the reduced number of trees available for analysis did not allow for them being considered events with equal confidence.

The position of all trees showing GD in a specific year was then used to assess spatial patterns of 33 debris flows reconstructed on the cone with large amounts of trees. Based on the spatial distribution of trees disturbed during particular events, four patterns of spatial activity can be distinguished. The four patterns are described in the following and illustrated with one characteristic example each in Fig. 7. invested into the formation of compression wood, this is why tree rings start to become smaller on the upslope side of the stem (core c). b Ring-width series of a $L$. decidua tree following stem burial in $\mathrm{AD}$ 1798

Pattern A: signs of debris-flow activity in the southern part of the cone

In flow pattern $\mathrm{A}$, illustrated with a debris flow dated to $\mathrm{AD}$ 1892, surges left the current channel at the dogleg formed at $1,350 \mathrm{~m}$ a.s.1. (Fig. 7a). Pattern A events follow the well-defined channel in the west-southwestern part of the forested cone. GD are commonly identified over a distance of $\sim 150 \mathrm{~m}$ in trees standing in the levees on either side of the channel. Our dendrogeomorphic results also indicate that all events reconstructed for the time prior to AD 1897 can be attributed to this flow pattern, namely: 1736, 1760, 1779, 1798, 1849, 1853, 1861, 1863, 1865, 1868, 1876, 1880 , and 1895 .

Pattern B: signs of debris-flow activity in the northernmost segments of the cone

Flow pattern B, represented in Fig. 7b with a debris flow dated to 1918, shows several breakout locations and a concentration of channel bank overtopping at about 1,320

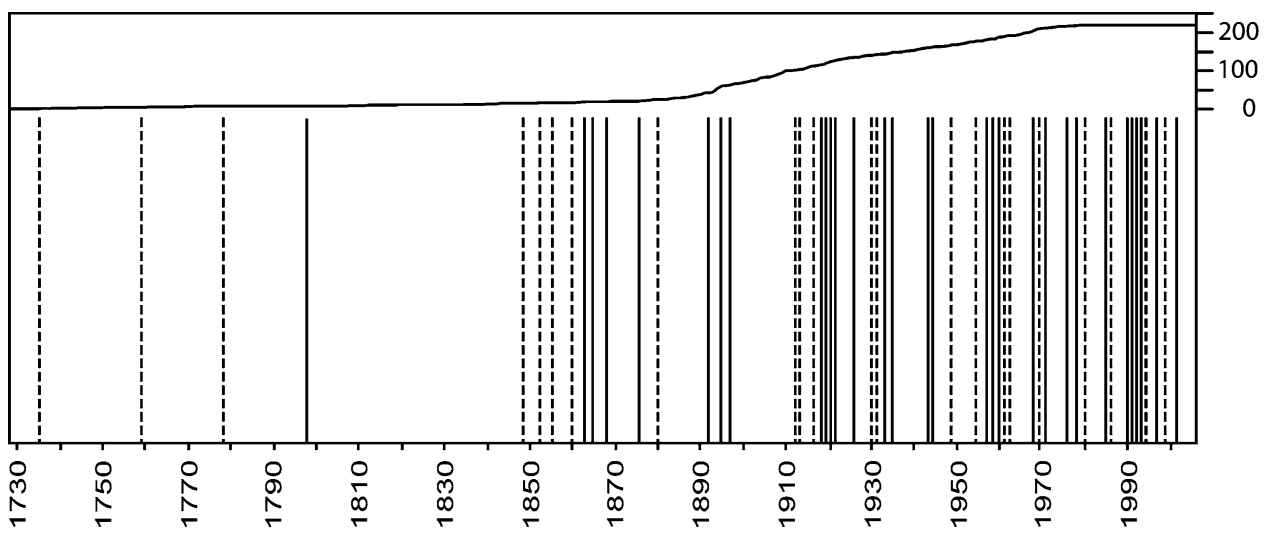

Fig. 6 Tree-ring based reconstruction of debris-flow activity at Geisstriftbach between AD 1736 and 2007 containing 53 events: 31 events could be identified in a very large number of growth disturbances (bold lines). In contrast, for the 22 events represented with dashed lines, there is good evidence for the existence of events in these years as well, but the reduced number of trees available for analysis did not allow for them being considered events with equal confidence. Sample depth (i.e., the number of increment cores, wedges and cross-sections available for analysis) is given with a solid line on top of the frequency 
Fig. 7 Location of trees on the Geisstriftbach cone showing growth disturbances during selected debris-flow events: a flow pattern A event in 1892; b flow pattern B event in 1918; c flow pattern $C$ event in 1971; and $\mathbf{d}$ flow pattern $\mathrm{D}$ event in 1992. For explanations see text (orthophoto: (c) swisstopo 2010, used with permission)
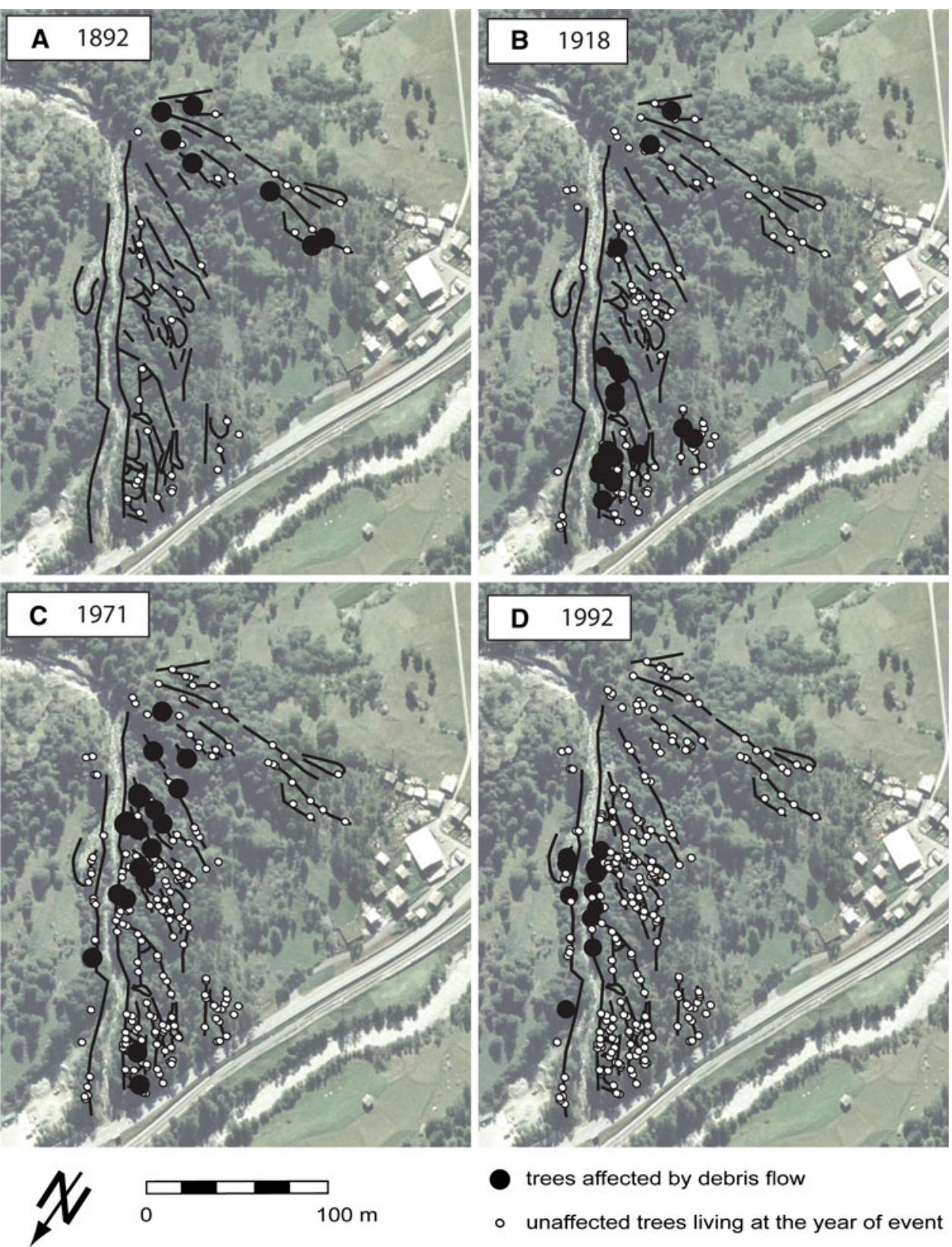

trees affected by debris flow

- unaffected trees living at the year of event to $1,330 \mathrm{~m}$ a.s.l. GD in trees associated with this flow pattern remain confined to the levee segments northeast of the channel that was active during pattern A events. Incidences with affected surfaces similar to those of AD 1918 can be identified in 1897, 1932, 1959, 1960, 1968 and 1978. It also becomes obvious from the tree-ring record that there must have been a drastic event towards the very end of the nineteenth century that was (1) able to shut off the west-southwestern part of the cone (i.e., the zone affected during pattern A events) and (2) capable of carving a new channel north-northwest of the abandoned one.
Pattern C: signs of debris-flow activity in the upper segments of the cone

Flow pattern C, displayed in Fig. 7c, is characterized by a concentration of disturbed trees in the upper segments of the cone. The debris flow of AD 1971 has been chosen for illustration, but pattern C events are also observed in 1919, 1921, 1933, 1985, 1986, or 1991. Pattern C events tend to overtop the active channel in a zone where vegetation is sparse and the shielding effect of the forest limited. It is also observed that channel overtopping at this location 
tends to result in events with larger travel distances on the cone than during pattern $\mathrm{B}$ events.

\section{Pattern D: signs of debris-flow activity in trees growing along the actual channel}

Pattern D events usually remain inside the levees of the current channel and only affect trees in the proximity of the channel, as exemplified with the event of 1992 in Fig. 7d. Other debris flows with flow pattern $\mathrm{D}$ are those dated to 1990, 1997, 2000, and 2002. Based on the intensity of GD observed in the tree-ring records and the predominance of strong tangential rows of traumatic resin ducts (TRD), we postulate that the 1992 debris flow transported large boulders. While the event did not deposit material on the cone, sizeable boulders of this debris flow were preserved in the lateral levees of the current channel.

\section{Discussion}

In the study we report here, increment cores, wedges and cross-sections extracted from 252 living $L$. decidua, $P$. abies and B. pendula trees allowed detection and dating of 1,344 growth disturbances (GD) attributed to 53 debrisflow events since AD 1736. In addition, four flow patterns of past events could be identified on the cone of the Geisstriftbach torrent (Valais, Swiss Alps).

On the basis of the evidence presented above, it was possible to complement the database of known debris flows from three to 53 events and to extend the chronology by almost two and a half centuries. In addition, we determined four flow patterns and outbreak locations for a majority of past events. Our reconstruction shows that the torrent passed at the southern limit of the cone before the very end of the nineteenth century and that the dogleg present in the present-day channel at $1,350 \mathrm{~m}$ a.s.l. did not exist before the 1890s. These observations are confirmed when the situation at Geisstriftbach is analyzed on old topographic sheet (Siegfried maps, 1:50,000), where the torrent is at the southern limit of the forest on the sheet of 1881. The dogleg and the "new" channel become first visible on the topographic sheet published in 1891, which is in concert with our reconstructions. We observe simultaneous changes in the sample depth shown in Fig. 6, indicating that the creation of the dogleg and the abandonment of the former main channel resulted in enhanced tree germination in those areas of the study site becoming protected from repeated debris-flow disturbance.

When talking about debris-flow histories, we also need to stress that tree-ring based reconstructions of past debrisflow activity remain minimum frequencies and that some events may have been missed as a result of tree selection in the field or through the fact that debris flows did not leave any signs in the trees present on the current-day cone surface. Missing information for debris flows is most obvious for the eighteenth and nineteenth century, when the number of trees available for analysis becomes steadily smaller and several sectors of the cone do no longer support trees of sufficient age. On the other hand, we are convinced that the method used was very successful in identifying a large majority of debris flows that overspilled onto the cone and of surges causing damage to trees growing in the channels' levees for events of the twentieth century.

Another reason why tree-ring records may only produce minimum frequencies stems from the fact that the approach used in this paper most certainly fails in determining the frequency of smaller flows, as these incidences usually remain confined in the channel without causing recordable damage to trees. This limitation is not, however, significant for hazard and risk studies, as it only truncates the debrisflow frequency for lower magnitude events. Most prudent debris-flow mitigation measures will rely on a high return period event, whose occurrence is more important than that of more frequently occurring smaller events.

On the other hand, it is possible that the scarcity of debris flows in the eighteenth and nineteenth centuries has systemintrinsic reasons. We could therefore hypothesize that the cooler "Little Ice Age" (Grove 2004) temperatures along with repeated snowfalls at low elevations during summer (Pfister 1999; Stoffel et al. 2008a, in review) would not only have prevented debris-flow events from being triggered from the high-elevation starting zone of the Geisstriftbach torrent, but that the lower atmospheric temperatures would also have had stabilizing effects on the local rock-glacier body and that they would thus have limited debris production (Lugon and Stoffel 2010). Consequently, limited debris production rates and smaller active layer of the rockglacier body would ultimately have resulted in (primarily) smaller debris-flow events (Stoffel 2010), which would, as a consequence, have remained inside the channel without leaving clearly visible signs of disturbance in trees growing on the cone (Hupp 1984; Jakob 1996).

As a result of warming atmospheric temperatures and a series of warm-wet summers in the early decades of the last century (Pfister 1999; Stoffel and Beniston 2006), we observe a clustering of debris-flow incidences in the late 1910s. This concentration of events, as well as the scarcity of debris flows during much of the Little Ice Age, is in concert with dendrogeomorphic debris-flow histories of neighboring watersheds. The twentieth century frequency obtained for the Geisstriftbach shows a strong resemblance with series reconstructed for the Wildibach (Randa, $46^{\circ} 05^{\prime} \mathrm{N}, 7^{\circ} 46^{\prime} \mathrm{E}$; unpublished data), Birchbach (St. Niklaus/Randa; $46^{\circ} 07^{\prime} \mathrm{N}$, $7^{\circ} 47^{\prime} \mathrm{E}$; Bollschweiler and Stoffel 2010) and Ritigraben (Grächen/St. Niklaus; $46^{\circ} 11^{\prime} \mathrm{N}, 7^{\circ} 49^{\prime} \mathrm{E}$; Stoffel and Beniston 
2006; Stoffel et al. 2008a) torrents and a comparable overall number of events for the twentieth century.

Yet another peak in debris-flow activity at Geisstriftbach is observed towards the end of the twentieth century, when increased rock-glacier movements have led to a major destabilization of the permafrost body and subsequent active-layer failure detachments (Kääb et al. 2007). Rockglacier movements are still in crisis in the area (Lugon and Stoffel 2010) and will continue to provide large quantities of mobilizable material into the debris-flow system.

Besides the availability of erodible sediments and channel recharge rates (Zimmermann et al. 1997; Jakob et al. 2005), we need to stress that the occurrence and seasonality of rainfall events capable of triggering debris flows are apparently undergoing changes in the larger study area as well (Stoffel and Beniston 2006; Stoffel et al. 2010). We observe that mean occurrence dates of debris flows have shifted by almost 2 weeks at Ritigraben over the last 150 year and that events have become much more frequent in August and September and, at the same time, exceptional in June and July. The same study also points to the fact that - as a result of changes in the seasonality and frequency of heavy precipitation events (Schmidli and Frei 2005; Beniston 2006)_debris flows have occurred more frequently in the late nineteenth and early twentieth century than they do today and that the number of heavy rains triggering debris flows would decrease in a future greenhouse climate by 2100 . These findings are contradicting earlier work on debris flows in the study area by Rebetez et al. (1997), but confirm results of Jomelli et al. (2004, 2007) analyzing future debris-flow frequency for torrents in the French Massif des Ecrins.

Given that the rock glacier in the departure zone of Geisstriftbach debris flows keeps on surging and that the channel is regularly being recharged with sufficient amounts of debris, the size and impacts of future summertime debris flows could be greater than currently because of warmer temperatures and higher precipitation intensities, even if the frequency of summer events is likely to decrease. Such larger magnitude, but more infrequent events can (1) erode the channel on the cone, (2) (partly) block its channel with lobate deposits or (3) provoke an overtopping of surges at the locations outlined in the results section. Hazard assessments will need to take account of such scenarios and the authorities involved will have to make sure that overspilling events and the spread of material on the cone will remain exceptional.

\section{Conclusion}

The present study represents an important contribution for the appreciation of debris-flow processes on cones and is a nice example on how dendrogeomorphic applications may help the reconstruction and understanding of debris flows in Alpine areas. At the same time, we have to admit that our overall comprehension of this and other geomorphic processes originating from high-elevation sites continues to remain in its infancy as soon as it comes to the assessment of climate change impacts on the number of occurrences (i.e. frequency) or the size (i.e. magnitude) of future events. More research is therefore needed for a better appraisal of these potentially dangerous processes and for an appropriate protection of humans and their assets in vulnerable mountain regions.

Acknowledgments This work has been undertaken in the context of the project RUFINE (no. 0931030100RA/8253; SFP-SRCE) and considerably benefited from the assistance of Michael Graupner, Oliver M. Hitz, Franziska Peter and David Sorg during fieldwork and analysis. The authors express their gratitude to Daniel Ariztegui, Louis Scuderi and an anonymous reviewer for their insightful comments.

\section{References}

Alestalo, J. (1971). Dendrochronological interpretation of geomorphic processes. Fennia, 105, 1-139.

Arbellay, E., Stoffel, M., \& Bollschweiler, M. (2010). Dendrogeomorphic reconstruction of past debris-flow activity using injured broad-leaved trees. Earth Surface Processes and Landforms, 35, 399-406.

Beniston, M. (2006). August 2005 intense rainfall event in Switzerland: Not necessarily an analog for strong convective events in a greenhouse climate. Geophysical Research Letters, 33, L05701.

Bollschweiler, M., \& Stoffel, M. (2007). Debris flows on forested cones-reconstruction and comparison of frequencies in two catchments in Val Ferret, Switzerland. Natural Hazards and Earth System Sciences, 7, 207-218.

Bollschweiler, M. \& Stoffel, M. (2010). Variations in debris-flow occurrence in an Alpine catchment: Reconstruction and implications for the future. Global and Planetary Change. doi: 10.1016/j.gloplacha.2010.05.006.

Bollschweiler, M., Stoffel, M., Ehmisch, M., \& Monbaron, M. (2007). Reconstructing spatio-temporal patterns of debris-flow activity using dendrogeomorphological methods. Geomorphology, 87, 337-351.

Bollschweiler, M., Stoffel, M., \& Schneuwly, D. M. (2008a). Dynamics in debris-flow activity on a forested cone-A case study using different dendroecological approaches. Catena, 72, 67-78.

Bollschweiler, M., Stoffel, M., Schneuwly, D. M., \& Bourqui, K. (2008b). Traumatic resin ducts in Larix decidua trees impacted by debris flows. Tree Physiology, 28, 255-263.

Braam, R. R., Weiss, E. E. J., \& Burrough, P. A. (1987). Spatial and temporal analysis of mass movement using dendrochronology. Catena, 14, 573-584.

Cook, E. R., \& Kairiukstis, L. A. (1990). Methods of dendrochronology-applications in the environmental sciences (p. 314). London: Kluwer.

Fantucci, R., \& Sorriso-Valvo, M. (1999). Dendrogeomorphological analysis of a slope near Lago, Calabria (Italy). Geomorphology, $30,165-174$.

Grove, J. M. (2004). Little Ice Ages: Ancient and Modern (p. 718). London: Routledge. 
Hupp, C. R. (1984). Geo-botanical evidence of late Quaternary mass wasting in block field areas of Virginia. Earth Surface Processes and Landforms, 8, 439-450.

Jakob, M. (1996). Morphometric and geotechnical controls of debris flow frequency and magnitude in southwestern British Columbia. Ph.D. dissertation, University of British Columbia at Vancouver, Vancouver, BC, Canada, $232 \mathrm{pp}$.

Jakob, M., Bovis, M., \& Oden, M. (2005). The significance of channel recharge rates for estimating debris-flow magnitude and frequency. Earth Surface Processes and Landforms, 30, 755-766.

Jakob, M., \& Hungr, O. (2005). Debris-flow hazards and related phenomena. Praxis (p. 739). Berlin: Springer.

Jomelli, V., Brunstein, D., Grancher, D., \& Pech, P. (2007). Is the response of hill slope debris flows to recent climate change univocal? A case study in the Massif des Ecrins (French Alps). Climatic Change, 85, 119-137.

Jomelli, V., Pech, P., Chochillon, C., \& Brunstein, D. (2004). Geomorphic variations of debris flows and recent climatic change in the French Alps. Climatic Change, 64, 77-102.

Kääb, A., Frauenfelder, R., \& Roer, I. (2007). On the response of rock glacier creep to surface temperature increase. Global and Planetary Change, 56, 172-187.

Labhart, T.P. (2004). Geologie der Schweiz, 6th edn. Ott Verlag: Thun, $211 \mathrm{pp}$.

Lugon, R. \& Stoffel, M. (2010). Rock-glacier dynamics and F-M relations of debris-flow activity in a high-elevation watershed: Ritigraben, Swiss Alps. Global and Planetary Change. doi: 10.1016/j.gloplacha.2010.06.004.

Mayer, B., Stoffel, M., Bollschweiler, M., Rudolf-Miklau, F., \& Hübl, J. (2010). Frequency and spread of hyperconcentrated flows on fans a dendrogeomorphic case-study from a dolomite catchment in the Austrian Alps extending back to AD 1800. Geomorphology, 118, 199-206.

McAuliffe, J. R., Scuderi, L. A., \& McFadden, L. D. (2006). Tree-ring record of hillslope erosion and valley floor dynamics: landscape responses to climate variation during the last 400 year in the Colorado Plateau, northeastern Arizona. Global and Planetary Change, 50, 184-201.

Pfister, C. (1999). Wetternachhersage. 500 Jahre Klimavariationen und Naturkatastrophen. Paul Haupt, Bern, Stuttgart, Wien, $304 \mathrm{pp}$.

Raetzo, H., Lateltin, O., Bollinger, D., \& Tripet, J. P. (2002). Hazard assessment in Switzerland-codes of practice for mass movements. Bulletin of Engineering Geology and the Environment, 61, 263-268.

Rebetez, M., Lugon, R., \& Baeriswyl, P. A. (1997). Climatic change and debris flows in high mountain regions: the case study of the Ritigraben torrent (Swiss Alps). Climatic Change, 36, 371-389.

Rinntech. (2009). http://www.rinntech.com/content/blogcategory/2/ 28/lang,english/.

Schmidli, J., \& Frei, C. (2005). Trends of heavy precipitation and wet and dry spells in Switzerland during the 20th century. International Journal of Climatology, 25, 753-771.

Schneuwly, D. M., Stoffel, M., \& Bollschweiler, M. (2009a). Formation and spread of callus tissue and tangential rows of resin ducts in Larix decidua and Picea abies following rockfall impacts. Tree Physiology, 29, 281-289.

Schneuwly, D. M., Stoffel, M., Dorren, L. K. A., \& Berger, F. (2009b). Three-dimensional analysis of the anatomical growth response of European conifers to mechanical disturbance. Tree Physiology, 29, 1247-1257.

Shroder, J. F. (1980). Dendrogeomorphology: Review and new techniques of tree-ring dating. Progress in Physical Geography, 4, 161-188.
Sorg, A., Bugmann, H., Bollschweiler, M., Stoffel, M. (2010). Debrisflow activity along a torrent in the Swiss Alps: Minimum frequency of events and implications for forest dynamics. Dendrochronologia. doi:10.1016/j.dendro.2009.11.002.

SRCE. (2007). Base de données des événements du Canton du Valais. Sion: Service des Routes et des Cours d'Eau.

Stoffel, M. (2008). Dating past geomorphic processes with tangential rows of traumatic resin ducts. Dendrochronologia, 26, 53-60.

Stoffel, M. (2010). Estimating magnitude-frequency relationships for debris flows-a case study from the Swiss Alps. Geomorphology, 116, 67-76.

Stoffel, M., \& Beniston, M. (2006). On the incidence of debris flows from the early Little Ice Age to a future greenhouse climate: A case study from the Swiss Alps. Geophysical Research Letters, 33, L16404.

Stoffel, M., \& Bollschweiler, M. (2008). Tree-ring analysis in natural hazards research-an overview. Natural Hazards and Earth System Sciences, 8, 187-202.

Stoffel, M., \& Bollschweiler, M. (2009). What tree rings can tell about earth-surface processes. Teaching the principles of dendrogeomorphology. Geography Compass, 3, 1013-1037.

Stoffel, M., Bollschweiler, M., Beniston, M. (2010). Rainfall characteristics for periglacial debris flows in the Swiss Alps: past incidences-future evolutions (in review).

Stoffel, M., Bollschweiler, M., Butler, D. R., \& Luckman, B. H. (2010b). Tree rings and natural hazards: A state-of-the-art (p. 505). Berlin: Springer.

Stoffel, M., Bollschweiler, M., \& Hassler, G. R. (2006). Differentiating events on a cone influenced by debris-flow and snow avalanche activity - a dendrogeomorphological approach. Earth Surface Processes and Landforms, 31, 1424-1437.

Stoffel, M., Bollschweiler, M., Leutwiler, A., \& Aeby, P. (2008a). Tree-ring reconstruction of debris-flow events leading to overbank sedimentation on the Illgraben cone (Valais Alps, Switzerland). The Open Geology Journal, 2, 36-47.

Stoffel, M., Conus, D., Grichting, M. A., Lièvre, I., \& Maître, G. (2008b). Unraveling the patterns of late Holocene debris-flow activity on a cone in the Swiss Alps: chronology, environment and implications for the future. Global and Planetary Change, $60,222-234$.

Stoffel, M., \& Hitz, O. M. (2008). Snow avalanche and rockfall impacts leave different anatomical signatures in tree rings of Larix decidua. Tree Physiology, 28, 1713-1720.

Stoffel, M., Lièvre, I., Conus, D., Grichting, M. A., Raetzo, H., Gärtner, H. W., et al. (2005a). 400 years of debris-flow activity and triggering weather conditions: Ritigraben, Valais, Switzerland. Arctic, Antarctic, and Alpine Research, 37, 387-395.

Stoffel, M., Schneuwly, D., Bollschweiler, M., Lièvre, I., Delaloye, R., Myint, M., et al. (2005b). Analyzing rockfall activity (1600-2002) in a protection forest-a case study using dendrogeomorphology. Geomorphology, 68, 224-241.

Strunk, H. (1997). Dating of geomorphological processes using denrogeomorphological methods. Catena, 31, 137-151.

Szymczak, S., Bollschweiler, M., Stoffel, M., \& Dikau, R. (2010). Debris-flow activity and snow avalanches in a steep catchment of the Valais Alps (Switzerland): Dendrogeomorphic reconstruction and identification of triggering rainfall events. Geomorphology, 116, 107-114.

Zimmermann, M., Mani, P., \& Romang, H. (1997). Magnitudefrequency aspects of alpine debris flows. Eclogae Geologicae Helvetiae, 90, 415-420. 